\title{
Pendidikan Islam Inklusif Pesantren ( Kajian Historis - Sosiologis di Indonesia )
}

\author{
Oleh : Syamsul Huda Rohmadi \\ ( Institute Agama Islam Negeri Surakarta ) \\ Syamsul_hr@gmail.com
}

\begin{abstract}
Abstrak
Transformasi pesantren ke arah modernitas untuk menyongsong pengaruh dari luar peranan pada kyai sebagai figur pemimpin. Ada pesantren yang tetap mempertahankan misi pesantren sebagai lembaga tafaqquh fiddin, akan tetapi ada juga pesantren yang didesain sebagai lembaga yang bergerak di bidang sosial ekonomi keagamaan di samping pengkajian kitab-kitab klasik sebagai ciri khas pesantren. Inklusif adalah keterbukaan sikap dalam menerima keberbedaan dengan tetap berinteraksi dalam kehidupan, sehingga dalam konteks kultur yang beraneka ragam. Perlunya pesantren lembaga pendidikan melihat proses transformasi sosial dan yang kedua pengembangan pesantren tidak tercerabut dari akar tradisinya

Kata Kunci : Islam Inklusif, Pesantren
\end{abstract}

\begin{abstract}
The transformation of pesantren toward modernity to meet the influence from outside role on kyai as leader figure. There is a boarding school that still maintains the mission of pesantren as a tafaqquh fiddin institution, but there are also pesantren designed as an institution engaged in the field of religious social economy in addition to the study of the classic books as a characteristic of pesantren.Inclusive is the openness of attitudes in accepting diversity by staying interacting in life, so in the context of diverse cultures. The need for pesantren educational institutions to see the process of social transformation and the second development of pesantren not tercerabut from the roots of tradition.
\end{abstract}

Keywords: Inclusive Islam, Boarding School. 


\section{Pendahuluan}

Kemajemukan Indonesia merupakan kekuatan sosial dan dengan keragaman yang indah apabila satu sama lain bersinergi dan saling bekerja sama untuk membangun bangsa. Namun, pada sisi lain, kemajemukan tersebut apabila tidak dikelola dan dibina dengan tepat dan baik akan menjadi pemicu dan penyulut konflik dan kekerasan yang dapat menggoyahkan sendi-sendi kehidupan berbangsa.

Konflik horizontal yang merupakan kerugian tidak saja jiwa dan materi tetapi juga disintegrasi antar sesama masyarakat Indonesia. ${ }^{1}$ Maka, disinilah diskursus dan implementasi Islam inklusif untuk menemukan tempatnya yang berarti dan tentu saja pendidikan menjadi satu faktor penting.

Pasca reformasi dengan runtuhnya Soeharto dari kekuasaannya, munculnya kebudayaan Indonesia cenderung mengalami disintegrasi dan kekerasan. Krisis moneter, ekonomi, dan politik yang bermula sejak 1997 mengakibatkan terjadinya krisis kultural di dalam kehidupan berbangsa dan bernegara. Berakhirnya sentralisme kekuasaan yang pada masa Orde Baru memaksakan monokulturalisme dan hegemoni kebudayaan mengandung implikasi negatif bagi rekonstruksi kebudayaan Indonesia yang plural. Berbarengan dengan proses otonomisasi dan desentralisasi kekuasaan serta pemerintahan, terjadi peningkatan gejala provisionalisme yang hampir tumpang tindih dengan etnisitas. Kecenderungan ini jika tidak terkendali akan dapat menimbulkan tidak hanya disintegrasi sosio-kultural yang amat parah, tetapi juga disintegrasi bangsa. ${ }^{2}$ Maka perlunya pendidikan sebagai grand design jangka panjang bagi bangsa.

Salah satu lembaga pendidikan yang sudah tua adalah pesantren, sebagai salah satu subkultur sosial yang seringkali disebut orang sebagai lembaga tradisional yang ada di Indonesia, tidak luput dari jangkauan proses tersebut. Eksistensinya akan selalu ditantang oleh perubahan sebagai sebuah kebutuhan yang mengalami pergeseran nilai. Kemampuan pesantren memenuhi tuntutan kebutuhan pendukungnya menjadi ujian bagi kelangsungan eksistensinya sehingga transformasi sosio-kultural yang ditempuhnya harus senantiasa memperhatikan perubahan yang terjadi dalam lingkungannya.

\footnotetext{
${ }^{1}$ Martin Van Bruinessen, "Genealogies of Islamic Radicalism in post-Suharto Indonesia", (Southeast Asia Research no 2, 2002), 117.

${ }^{2}$ Hawasi, "Aktualisasi Paradigma Multikulturalisme dalam Budaya Indonesia yang Plural", Proceeding Seminar Nasional PESAT 2005 di Universitas Gunadarma.
} 
Pesantren sebagai pusat kegiatan keagamaan murni (tafaqquh fiddin) untuk penyiaran agama Islam. Itulah identitas pesantren pada awal perkembangannya. Identitas lain yang sering melekat pada pesantren adalah sebagai lembaga pendidikan Islam tradisional yang mengajarkan Islam ortodoks secara konservatif.

Maka pesantren perlunya melakukan evolusi mengikuti perkembangan dan perubahan. Atau pesantren dituntut mampu untuk melakukan inovasi-inovasi secara interen maupun ekstern untuk merespon perubahan. Salah satunya bagaimana pesantren mampu membuka diri sebagai bagian bangsa dalam kemajemukannya.

\section{Inklusifitas dan Ajaran Islam}

Inklusif adalah keterbukaan sikap dalam menerima keberbedaan dengan tetap berinteraksi dalam kehidupan, sehingga dalam konteks kultur yang beraneka ragam, atau disebut multikultural. Secara sederhana multikultural berarti “ keberagaman budaya. ${ }^{3}$ Sebenarnya, ada tiga istilah yang kerap digunakan secara bergantian untuk menggambarkan masyarakat yang terdiri keberagaman tersebut -baik keberagaman agama, ras, bahasa, dan budaya yang berbeda- yaitu pluralitas (plurality), keragaman (diversity), dan multikultural (multicultural). Ketiga ekspresi itu sesungguhnya tidak merepresentasikan hal yang sama, walaupun semuanya mengacu kepada adanya 'ketidaktunggalan'.

Apabila pluralitas sekadar merepresentasikan adanya kemajemukan (yang lebih dari satu), multikultural memberikan penegasan bahwa dengan segala perbedaannya itu mereka adalah sama di dalam ruang publik. Multikulturalisme menjadi semacam respon kebijakan baru terhadap keragaman. Dengan kata lain, adanya komunitas-komunitas yang berbeda saja tidak cukup; sebab yang terpenting adalah bahwa komunitaskomunitas itu diperlakukan sama oleh negara. Oleh karena itu, multikultural sebagai sebuah gerakan menuntut pengakuan (politics of recognition) ${ }^{4}$ terhadap semua

\footnotetext{
${ }^{3}$ Scott Lash dan Mike Featherstone (ed.), Recognition and Difference: Politics, Identity, Multiculture (London: Sage Publication, 2002), 2-6.

${ }^{4}$ Politics of recognition dikemukan oleh Charles Taylor pada 1992 di depan kuliah terbuka di Princenton University. Mulanya gagasannya adalah gagasan politik yang kemudian berkembang di kajian lain, flsafat, sosiologi, budaya dan lainnya. Gagasanya dipengaruhi oleh padangan Jean-Jacques Rousseau dalam Discourse Inequality dan kesamaan martabat (equal dignity of human rights) yang dicetuskan Immanuel Kant. Gagasan Taylor bersumber pada pertama, bahwa sesungguhnya harkat dan martabat manusia adalah sama. Kedua, pada dasarnya budaya dalam masyarakat adalah berbeda-beda, oleh karena itu membutuhkan hal yang ketiga, yaitu pengakuan atas bentuk perbedaan budaya oleh semua element sosial-budaya, termasuk juga negara. Charles Taylor. "The Politics of Recognation" dalam Amy Gutman.
} 
perbedaan sebagai entitas dalam masyarakat yang harus diterima, dihargai, dilindungi serta dijamin eksistensinya.

Inklusif adalah sikap bagaimana seseorang dalam menerima keberbedaan, dengan ikut aktif dalam kehidupan kebinekaan, ini akan memberikan sikap pada semua orang dalam tataran menghargai dan menghormati antar sesama. Islam mengajarkan bahwa manusia adalah sama. Manusia diciptakan dalam berbagai macam suku dan bangsa berbeda untuk saling melengkapi (complementing) dan bekerjasama (cooperating), ${ }^{5}$ oleh karenanya, muslim seharusnya tidak menonjolkan etnosentrisme, tetapi harus bersikap inklusif dan mau belajar dari yang lain. Di sisi lain dijelaskan dalam al Qur'an bahwa ummah wasath dan khayr ummah, ${ }^{6}$ ini artinya kaum muslimin harus bisa mewujudkan diri sebagaimana dalam teks Al Qur'an, inilah yang memerlukan pelaksanaan bagi umat dalam masyarakat.

Islam predikat sebagai sebaik-baik umat (khaira ummah) sejatinya termanifestasikan dalam tiga hal; pertama, umat muslim dapat hidup berdampingan dengan umat lain yang berbeda dengan dirinya, bukan hidup terpisah dan menutup diri dari kehidupan global yang menjadi keniscayaan; kedua, persatuan kaum muslimin dan solidaritas Islam tidak boleh mengarah kepada tindakan etnosentris atau eksploitasi materi maupun tindakan agresi, sebaliknya umat muslim harus kooperatif dalam menjaga perdamaian, serta mengedepankan moralitas; ketiga, umat muslim seharusnya mau mendengar dan belajar dari pengalaman orang lain dan kemudian mengambil halhal yang baik. ${ }^{7}$

Konteks sejarah masyarakat Islam sudah mengukir sebagain ajaran yang inklusif. Dengan menerima dan mempraktekan prilaku pluralis bukan saja terhadap mereka yang berpaham beda, akan tetapi, kepada mereka yang berkeyakinan tak sama

Multiculturalism, Examining the Politics of Recognation (Princenton: Princenton University Press, 1994), 18.

5 "Hai manusia, Sesungguhnya Kami menciptakan kamu dari seorang laki-laki dan seorang perempuan dan menjadikan kamu berbangsa - bangsa dan bersuku-suku supaya kamu saling kenal-mengenal. Sesungguhnya orang yang paling mulia diantara kamu disisi Allah ialah orang yang paling taqwa diantara kamu. Sesungguhnya Allah Maha mengetahui lagi Maha Mengenal.” (QS. Al-Hujurat:13)

6 "Dan demikian (pula) Kami telah menjadikan kamu (umat Islam), umat yang adil dan pilihan.."(QS. AlBaqarah: 143), dalam "Dan hendaklah ada di antara kamu segolongan umat yang menyeru kepada kebajikan, menyuruh kepada yang ma'ruf dan mencegah dari yang munkar; merekalah orang-orang yang beruntung." (QS. Ali Imran: 104)

${ }^{7}$ Muammar, M. Arfan, dkk. Studi Islam: Perspektif Insider/Outsider. (Yogyakarta: IRCiSoD,2013) h. 245-246 atau dalam Fathi Osman, Islam and Human Right, The Challenge to Muslim and The World, dalam Rethinking Islam and Modernity, ed. Abdel Wahab El-Effandi (London: The Islamic Foundation, 2001), 31 
seperti kepada masyarakat Yahudi, Nashrani, dan kepercayaan-kepercayaan lainnya. Sebagaimana yang diungkapkan oleh Fathi Osman bahwa ; berbeda agama dalam minoritas di wilayah muslim menjalankan profesinya sesuai dengan yang dimiliki. Sebagian penukar uang dan para penghubung di Syiria adalah orang Yahudi, sementara kebanyakan tabib dan juru tulis adalah orang-orang Yahudi. Pemimpin Nashrani di Bagdad adalah tabib Khalifah, dan masih banyak Yahudi yang mendapatkan posisi di istana Khalifah. Bahkan Khalifah Fatimiah al-Aziz mempunyai seorang menteri Nashrani dan menunjuk seorang Yahudi sebagai Gubernur di Siria". 8

Menurut Bhamra dan Lofthouse ${ }^{9}$, dengan istilah sustainable development sebagai proses menuju sustainability yang di dasarkan pada empat prinsip yaitu keadilan hari ini, keadilan lingkungan, intergenerasional keadilan, dan pelayanan. Ini berarti, di dalam kerangka pikir sustainable development, semua kegiatan produksi dan konsumsi menuntut setiap personal untuk tidak melupakan bahwa setiap individu atau kelompok tidak melakukan kegiatan produksi dan konsumsi yang mengganggu kualitas hidup kelompok lain, lingkungan, generasi masa depan, dan bertanggung jawab atas kualitas bumi di masa depan.

Dari definisi tersebut selain menuntut setiap manusia baik secara individu maupun kelompok untuk memiliki kearifan terhadap lingkungan dengan tanpa membuat suatu tindakan yang dapat merusakan masa depan generasi mendatang, juga menunjukkan bahwa upaya penyelamatan lingkungan adalah upaya untuk keberlanjutan ekonomi dan kehidapan sosial manusia.

\section{Kyai, Pesantren dan Tantangan}

Pendidikan pesantren sudah terjadi pada masa kolonial. Lembaga ini berperan menentang penetrasi kolonialisme yang pada akhirnya melakukan strategi ekslusif atau menutup dan menghindar dari persoalan-persoalan sosial. Peran seperti ini berlanjut sampai pada masa kemerdekaan. Sebagai dampaknya pesantren menjadi terisolisir dari persoalan-persolan sosial dan kurang diperhitungkan eksistensinya secara nasional.

\footnotetext{
${ }^{8}$ Mohamed Fathi Osman, The Childern of Adam; An Islamic Perspective on Pluralism, Islam, Pluralisme dan Toleransi Keagamaan; Pandangan Alqur'an, Kemanusiaan, Sejarah, dan Peradaban, (Jakarta : Paramadina, 2006), 63-64

${ }^{9}$ Bhamra, T., dan Lofthouse, V., Design for Sustainability: A practical approach, A practical Approach, (Gower Publishing Limited, Hampshire, 2007), 57
} 
Kedudukan kyai dalam pesantren sebagai basis institusi utama. Hal ini didasarkan pada kenyataan bahwa di dalam bangunan pesantren kyai merupakan otoritas tunggal dalam penafsiran keagamaan sekaligus sebagai penjelmaan dari paham keagamaan itu sendiri. ${ }^{10}$ Kyai dianggap sebagai penyalur kemurahan Tuhan kepada santri-santri dan masyarakat sekitarnya. Posisi kyai dilihat sebagai puncak karir seorang santri dan pesantren menjadi sarana proses mobilisasi sosial. Pada faktor kedua, didukung kenyataan bahwa kedudukan kyai selalu mendapat tempat terhormat di tengah masyarakat sekitar pesantren. Kyai mempunyai otoritas yang tinggi di tengah tempat tinggalnya. Sikap hidup yang dibangun kyai di pesantren mempengaruhi pola kehidupan sosial keagamaan masyarakat sekitar pesantren berada. ${ }^{11}$ Dalam kerangka inilah kyai menjadi agen proses intensifikasi keislaman masyarakat yang bersifat inklusif.

Tantangan pesantren dalam era global adalah tidak hanya lokal bangsa akan tetapi konteks internasional, menjadi tantangan sekaligus sebagai desain pengembangan pendidikannya, sebagaimana Steve Fuller mengatakan tiga tantangan dalam era globalisasi, yaitu, pertama adanya hegemoni Barat dalam bidang politik, ekonomi, sosial dan ilmu pengetahuan. Komunitas, utamanya negara-negara berkembang, perlu mempelajari sebab-sebab dari hegemoni barat dalam bidang-bidang tersebut dan mengambil langkah-langkah seperlunya mengatasinya, sehingga dapat sejajar dengan dunia barat. ${ }^{12}$ Kedua, esensialisasi budaya. Dalam hal ini inklusivitas berupaya mencari esensi budaya tanpa harus jatuh ke dalam pandangan yang xenophobia dan etnosentrisme. Inklusivitas dapat melahirkan tribalisme yang sempit yang pada akhirnya merugikan komunitas itu sendiri di dalam era globalisasi. Ketiga, proses globalisasi, bahwa globalisasi bisa memberangus identitas dan kepribadian suatu budaya. ${ }^{13}$

Tradisi Nabi Muhammad SAW. sejarah peradaban Islam sebagai ajaran Islam inklusif adalah lahirnya deklarasi Nabi Muhammad SAW di Madinah (Piagam Madinah). Dua prinsip Islam inklusif dalam Piagam Madinah: pertama; semua pemeluk

\footnotetext{
${ }^{10}$ Jajat Burhanuddin,"Ulama dan Politik Pembentukan Umat: Sekilas Pengalaman Sejarah Indonesia," dalam Jajat Burhanuddin dan Ahmad Baedlowi, Transformasi Otoritas Keagamaan: Pengalaman Islam Indonesia (Jakarta; Gramedia, 2003), 22.

${ }^{11}$ Tentang hal ini lihat Dawam Rahardjo, "Kyai dalam Perubahan Sosial," dalam Pesantren, No. 4/ Vol. II/1985, 20-29.

${ }^{12}$ Kymlica W.. Multicultural, Citizenship: a Liberal Theory of Minority Rights (Oxford: Clarendon Press, 1995), 85.

${ }^{13}$ Steve Fuller, "Social Epistemology as a Critical Philosophy of Multiculturalism" dalam Ram Mahalingan dan Cameron McCarthy, Multiculturalism Curriculum, 2002. 15-36 sebagaimana dikutip oleh H.A.R. Tilaar, 84-85.
} 
Islam adalah satu umat walaupun mereka berbeda suku bangsa. Kedua, hubungan antara komunitas muslim dengan non muslim didasarkan pada prinsip-prinsip: (Berinteraksi secara baik dengan sesama tetangga; Saling membantu dalam menghadapi musuh bersama; Membela mereka yang teraniaya, Saling menasihati; Menghormati kebebasan beragama).

Dari deskripsi konseptual di atas, Muslim sejatinya menghargai keberagaman dan perbedaan sebagai landasan utama hak asasi manusia, tidak melakukan diskriminasi, tidak menjelekkan umat lain, atau memandang rendah mereka. Pada dasarnya tidak ada persoalan legalistik dalam konteks kesetaraan Muslim-nonMuslim. ${ }^{14}$ Istilah dzimmi yang muncul dalam tradisi Islam, untuk merujuk pada masyarakat non-Muslim yang hidup di negara Islam.

Secara garis besar ada tiga tipe kyai dalam penerimaan program pengembangan masyarakat. Pertama, kyai yang menerima program pengembangan masyarakat secara hati-hati. Kedua, kyai yang cukup hanya responsif. Ketiga, kyai yang bukan saja menerima tetapi bahkan langsung memikirkan implementasinya dalam pola atau sistem manajemen pesantrennya. Dua kategori kyai yang terakhir ini bisa dikatakan mempunyai wawasan yang kuat mengenai program pengembangan masyarakat, sedangkan kyai kategori pertama memerlukan pendekatan khusus, karena biasanya sulit menerima gagasan baru. ${ }^{15}$

Diskursus inklusivisme pesantren dalam pendidikan adalah identitas, keterbukaan, diversitas budaya dan transformasi sosial. Identitas sebagai salah satu elemen dalam pendidikan mengandaikan bahwa peserta didik ( santri ) dan guru ( kyai ) merupakan satu individu atau kelompok yang merepresentasikan satu kultur tertentu dalam masyarakat. Identitas pada dasarnya inheren dengan sikap pribadi ataupun kelompok masyarakat, karena dengan identitas tersebutlah, mereka berinteraksi dan saling mempengaruhi satu sama lain, termasuk pula dalam interaksi antar budaya yang berbeda. Dengan demikian dalam pendidikan Islam inklusif, identitas-identitas tersebut diasah melalui interaksi, baik internal budaya (self critic) maupun eksternal budaya.

\footnotetext{
${ }^{14}$ Dikutip dari Amin Abdullah, Studi Islam, Ilmu Humaniora, dan Sosial Sebuah Perspektif Terpadu, dalam Memahami Hubungan Antar Agama, oleh Wiwik Setiyani dalam eprints.sunan.ampel.ac.id/625/1/wiwik1setyni.pdf. Akses: 10 Nopember 2016

${ }^{15}$ Erfan Maryono, “Aktualisasi Peran Kemasyarakatan Pesantren: Refleksi Pengalaman LPSM,” dalam Pesantren No. 3/Vol. V/1998, 33
} 
Oleh karena itu, identitas lokal atau budaya lokal merupakan muatan yang harus ada dalam pendidikan Islam inklusif di pesantren.

Dalam masyarakat ditemukan pelbagai individu atau kelompok yang berasal dari budaya berbeda, demikian pula dalam pendidikan, diversitas tersebut tidak bias atau dielakkan. Diversitas budaya itu bisa ditemukan di kalangan santri maupun kyai yang terlibat -secara langsung atau tidak- dalam satu proses pendidikan. Diversitas itu juga bisa ditemukan melalui pengkayaan budaya-budaya lain yang ada dan berkembang dalam konstelasi budaya, lokal, nasional dan global. Oleh karena itu, pendidikan Islam inklusif bukan merupakan satu bentuk pendidikan monokultur, akan tetapi model pendidikan yang berjalan di atas rel keragaman. Diversitas budaya ini akan mungkin tercapai dalam pendidikan jika pendidikan itu sendiri mengakui keragaman yang ada, bersikap terbuka (openess) dan memberi ruang kepada setiap perbedaan yang ada untuk terlibat dalam satu proses pendidikan.

Pesantren dan pendidikan inklusif, perlunya kurikulum dan implementasinya, ada lima dimensi yang dikembangkan Banks yaitu, pertama, adanya integrasi pendidikan dalam kurikulum (content integration) yang di dalamnya melibatkan keragaman dalam satu kultur pendidikan yang tujuan utamanya adalah menghapus prasangka. Kedua, konstruksi ilmu pengetahuan (knowledge construction) yang diwujudkan dengan mengetahui dan memahami secara komperhensif keragaman yang ada. Ketiga, pengurangan prasangka (prejudice reduction) yang lahir dari interaksi antar keragaman dalam kultur pendidikan. Keempat, pedagogik kesetaraan manusia (equity pedagogy) yang memberi ruang dan kesempatan yang sama kepada setiap element yang beragam. Kelima, pemberdayaan kebudayaan sekolah (empowering school culture). Hal yang kelima ini adalah tujuan dari pendidikan multikultur yaitu agar sekolah menjadi element pengentas sosial (transformasi sosial) dari struktur masyarakat yang timpang kepada struktur yang berkeadilan. ${ }^{16}$ Dalam pesantren memungkin untuk dari kurikulum, proses dan evaluasi pendidikan Islam inklusif.

\footnotetext{
${ }^{16}$ James A. Banks. "Multicultural Education: Historical Development, Dimensions, and Practice" 3-24.
} 


\section{Diskursus Pesantren dan Islam Inklusif}

Negara Indonesia merupakan negara yang memiliki banyak problem tentang eksistensi sosial, etnik, dan kelompok keagamaan yang beragam. ${ }^{17}$ Maka perlunya pembelajaran Iklusif dikelola dengan baik terhadap keberadaan multietnik, multibudaya, dan multiagama yang ada di Indonesia. Problem yang adalah adanya upaya penyeragaman atau sering disebut pendidikan Islam monokulturalis dalam berbagai kehidupan santri dan kyai dalam pembelajarannya.

Selama Orde Baru berkuasa, pemerintah mengabaikan terhadap perbedaan yang ada, baik dari segi suku, bahasa, agama, maupun budayanya. ${ }^{18}$ Semboyan "Bhinneka Tunggal Ika"19 pun diterapkan secara berat sebelah. Artinya, semangat keika-an lebih menonjol dari pada semangat ke-bhinneka-annya dalam pengelolaan negara Indonesia. Pengelolaan negara dengan penekanan pada semangat ke-ika-an dari pada semangat ke-bhinneka-an tersebut sangat mewarnai konsep dan praktik pendidikan di Indonesia $^{20}$ termasuk pendidikan Islam di pesantren.

Pendidikan yang diperhatikan adalah kurikulum, kurikulum pesantren perlunya mengangkat dan menguatkan tentang sikap nilai-nilai Islam inklusif untuk dijadikan dasar dalam perencanaan, implementasi, dan evaluasi kurikulum suatu lembaga pendidikan pesantren. Sebagaimana prinsip-prinsip pengembangan kurikulum yang bermuatan nilai-nilai multikultural. Prinsip yang dimaksud adalah "beragam dan terpadu." Prinsip ini dijelaskan sebagai berikut: "Kurikulum dikembangkan dengan memperhatikan keragaman karakteristik peserta didik, kondisi daerah, jenjang dan jenis pendidikan, serta menghargai dan tidak diskriminatif terhadap perbedaan agama, suku, budaya, adat istiadat, status sosial ekonomi, dan jender. Kurikulum meliputi substansi

\footnotetext{
${ }^{17}$ Lihat Musa Asy'arie, "Pendidikan Multikultural dan Konflik Bangsa", dalam Harian Kompas, Edisi Jum'at, 3 September 2004.

${ }^{18}$ Lihat Azyumardi Azra, "Identitas dan Krisis Budaya: Membangun Multikulturalisme Indonesia," dalam Makalah, disampaikan pada Simposium Internasional Jurnal Antropologi Indonesia ke-3, Membangun Kembali Indonesia yang Bhinneka Tunggal Ika: Menuju Masyarakat Multikultural, 16-19 Juli 2002, di Universitas Udayana, Denpasar, Bali, 2. Lihat juga, Abdul Munir Mulkhan, "Pendidikan Monokultur Versus Multikultural dalam Politik" dalam Harian Kompas, Edisi Sabtu, 18 September 2004.

${ }^{19}$ Semboyan ini memiliki pengertian bahwa Indonesia merupakan salah satu bangsa yang terdiri dari beragam suku dan ras, yang mempunyai budaya, bahasa, dan agama yang berbeda-beda tetapi dalam kesatuan Indonesia. Dalam catatan Leo Suryadinata dkk., Indonesia memiliki 250 kelompok suku, 250 lebih bahasa lokal, 13.000 pulau, dan 5 agama resmi. Lebih jauh tentang ini lihat Leo Suryadinata dkk., Indonesia's Population: Etnicity and Religion in a Changing Political Landscape (Singapore: Institute of Southeast Asian Studies, 2003), 30, 71, 104, dan 179.

${ }^{20}$ Lihat H.A.R. Tilaar, "Pendidikan Multikultural" dalam H.A.R. Tilaar, Kekuasaan dan Pendidikan: Suatu Tinjauan dari Perspektif Studi Kultural (Magelang: Indonesia Tera, 2003), 165-66.
} 
komponen muatan wajib kurikulum, muatan lokal, dan pengembangan diri secara terpadu, serta disusun dalam keterkaitan dan kesinambungan yang bermakna dan tepat antar substansi." 21

Proses pendidikan yang terjadi di lembaga-lembaga pendidikan Islam, seperti madrasah, sekolah Islam, dan pesantren. Ada beberapa ukuran, sebagaimana menurut M. Amin Abdullah, terlihat pada "proses pendidikan dan pengajaran agama pada umumnya yang lebih menekankan sisi keselamatan individu dan kelompoknya sendiri daripada keselamatan yang dimiliki dan didambakan oleh orang lain di luar diri dan kelompoknya sendiri". 22

Sehingga implementasi pendidikan pesantren ada beberapa yang menyebabkan kristalisasi kehidupan menjadi (output) santri yang dirinya sendiri tanpa melihat keragaman orang lain dan komunitas sosial yang kompleks, ini disebabkan beberapa hal, sebagaimana menurut Abdul Munir Mulkhan, indikatornya terlihat pada: pertama; terbatasnya ruang perbedaan pendapat antara kyai ( guru ) dengan santri ( peserta didik ), dan atau antara santri ( peserta didik ) satu dengan santri ( peserta didik ) lainnya dalam sistem pendidikan Islam, sehingga proses pembelajarannya bersifat indoktrinatif; dan kedua; fokus pendidikannya hanya pada pencapaian kemampuan ritual dan keyakinan tauhid, dengan materi ajar pendidikan Islam yang bersifat tunggal, yaitu benar-salah dan baik-buruk yang mekanistik. ${ }^{23}$

Sistem Pendidikan Nasional yang selama ini dalam praktek pembelajarannya "kurang inklusif” dalam proses, juga dalam pendidikan di lembaga Islam, hal ini dilihat ada 3 (tiga) indikator proses pendidikan Islam yang eksklusif, dogmatik, dan kurang menyentuh aspek moralitas. Ketiga indikator tersebut adalah: pertama; guru lebih sering menasihati peserta didik dengan cara mengancam, kedua; guru hanya mengejar

\footnotetext{
${ }^{21}$ Pusat Kurikulum Balitbang Depdiknas RI, "Bab II: Prinsip Pengembangan Kurikulum" dalam Kurikulum Tingkat Satuan Pendidikan (KTSP) (Jakarta: Puskur Balitbang Depdiknas, 2006), 4. Prinsip pengembangan kurikulum lainnya adalah: (1) berpusat pada potensi, perkembangan, kebutuhan, dan kepentingan peserta didik dan lingkungannya; (3) tanggap terhadap perkembangan ilmu pengetahuan, teknologi, dan seni; (4) relevan dengan kebutuhan kehidupan; (5) menyeluruh dan berkesinambungan; (6) belajar sepanjang hayat; dan (7) seimbang antara kepentingan nasional dan kepentingan daerah.

${ }^{22}$ Lihat M. Amin Abdullah, "Pengajaran Kalam dan Teologi di Era Kemajemukan: Sebuah Tinjauan Materi dan Metode Pendidikan Agama" dalam Tashwirul Afkar, Jurnal Refleksi Pemikiran Keagamaan dan Kebudayaan, Edisi No. 11 Tahun 2001, 14.

${ }^{23}$ Lihat Abdul Munir Mulkhan, "Humanisasi Pendidikan Islam" dalam Tashwirul Afkar, Jurnal Refleksi Pemikiran Keagamaan dan Kebudayaan, Edisi No. 11 Tahun 2001, 17-18. Bandingkan dengan Muhammad Ali, "Pendidikan Pluralis-Multikulturalis" dalam Harian Kompas, Edisi 26 April 2002, dan Ahmad Fuad Fanani, "Pendidikan Pluralis-Multikultural dan Liberatif" dalam Harian Kompas, Edisi 3 Juli 2002.
} 
standar nilai akademik sehingga kurang memperhatikan budi pekerti dan moralitas anak, serta ketiga kecerdasan intelektual peserta didik tidak diimbangi dengan kepekaan sosial dan ketajaman spiritualitas beragama. ${ }^{24}$

Tipologi pendidikan Islam mempunyai tiga model yang diterapkan lembagalembaga pendidikan Islam. Pertama, model "eksklusif” di mana siswa yang berbedabeda agama hanya menerima satu pendidikan agama konvensional yang sesuai dengan agama sekolah yang diajarkan guru agama. Kedua, model "inklusif" di mana siswa yang berbeda-beda agama mempelajari ajaran beberapa agama. Dalam model ini, pendidikan agama bersifat non-confessional yang menekankan aspek kognitif, siswa memahami dan membandingkan ajaran beberapa agama, menemukan nilai-nilai persamaan antar agama. ${ }^{25}$ Ketiga, model "pluralis" di mana siswa mendapatkan dua “pendidikan agama". Yang pertama, siswa menerima pendidikan agama confessional sebagaimana diatur di dalam perundangan pendidikan. Selain itu, siswa wajib mengikuti "pendidikan keagamaan" non-confessional sesuai dengan agama sekolah. ${ }^{26}$

Pesantren sebagai lembaga pendidikan Islam di Indonesia yang pada umumnya menyelenggarakan berbagai satuan pendidikan—baik dalam bentuk sekolah maupun madrasah-juga seyogyanya menjadikan prinsip pengembangan kurikulum yang bermuatan nilai-nilai Islam inklusif tersebut dalam kegiatan perencanaan, implementasi, dan evaluasi kurikulumnya. Namun dalam praktiknya, butir ini tidak mudah dilakukan oleh pesantren, terutama pesantren tradisional (salafiyah). ${ }^{27}$ Bagi pesantren tradisional, kegiatan perencanaan, implementasi, dan evaluasi kurikulum merupakan kegiatan yang belum populer di kalangan pengelola pesantren. Kegiatan pendidikan di pesantren tradisional pada umumnya merupakan hasil improvisasi dari seorang kyai secara intuitif

\footnotetext{
${ }^{24}$ Lihat Abdurrahman Mas’ud, "Format Baru Pola Pendidikan Keagamaan pada Masyarakat Multikultural dalam Perspektif Sisdiknas" dalam Mu'amar Ramadhan dan Hesti Hardinah (ed.), Antologi Studi Agama dan Pendidikan (Semarang: CV Aneka Ilmu, 2004), 87-88.

${ }^{25}$ Sebagaimana yang diungkapkan oleh Fathi Osman dengan menegaskan bahwa pluralitas adalah bagian penting dari peradaban yang secara teologi didasarkan pada konsep kesamaan (common platform atau kalimatun sawa') agama-agama.( ${ }^{25}$ Mohamed Fathi Osman, The Childern of Adam; An Islamic Perspective on Pluralism, (terj.) Islam, Pluralisme dan Toleransi Keagamaan; Pandangan Alqur'an, Kemanusiaan, Sejarah, dan Peradaban, Paramadina, Jakarta, 2006. h 69-70)

${ }^{26}$ Listia dkk., Problematika Pendidikan Agama di Sekolah: Hasil Penelitian tentang Pendidikan Agama di Yogyakarta 2004-2006, (Yogyakarta: Interfidei, 2007).

${ }^{27}$ Pesantren tradisional dapat dipahami sebagai pesantren yang memelihara bentuk pengajaran teks klasik dan pendidikan moral sebagai inti pendidikannya. Lihat Ronald Alan Lukens-Bull, Jihad ala Pesantren di Mata Antropolog Amerika (Yogyakarta: Gama Media, 2004), 84-5.
} 
yang disesuaikan dengan perkembangan pesantrennya. ${ }^{28}$ Dengan demikian, pengembangan kurikulum pesantren tradisional sangat ditentukan oleh seorang kyai, sehingga nilai-nilai Islam inklusif — terutama nilai demokrasi dan keadilan—agaknya tidak ditemukan dalam pengembangan kurikulum pesantren tradisional.

Sedangkan pesantren modern (khalafiyah) $^{29}$ dalam batas tertentu telah melakukan kegiatan pendidikannya berdasarkan program yang telah direncanakan oleh seorang kyai dan para pembantunya. Implementasi program pendidikan yang dilakukan juga dievaluasi demi perbaikan di masa yang akan datang. Dengan demikian, pengembangan kurikulum pesantren modern ditentukan oleh kyai dan para ustadz yang ada di pesantren tersebut, sehingga prinsip Islam inklusif diasumsikan ada dalam pengembangan kurikulum pesantren modern.

\section{Urgensi Pesantren dalam Inklusifitas}

Pesantren juga mengalami eksperimen dalam menghadapi pemerintahan yang menekankan pada pembangunan ekonomi di masa Orde Baru. Sudah tentu hal ini tidak terjadi pada masa orde sebelumnya yang lebih menekankan pada pembangunan di bidang politik. ${ }^{30}$ Dengan jargon pembangunan ekonomi, pesantren menjadi ajang propaganda sosialisasi demi tercapainya pembangunan. Bertitik tekan pada pertumbuhan ekonomi pemerintah Orde Baru menaruh harapan kepada pesantren untuk menjadi salah satu agen perubahan dan pembangunan masyarakat. Sesuai dengan ideologi developmentalisme pemerintah Orde Baru, pembaruan pesantren dalam masa ini lebih diarahkan pada fungsionalisasi pesantren sebagai salah satu pusat penting bagi pembangunan masyarakat. Dengan posisi dan kedudukannya yang khas pesantren diharapkan menjadi alternatif kampanye pembangunan yang berpusat pada masyarakat.

Pemikiran tersebut didasarkan pada kenyataan bahwa masyarakat merasakan manfaat pondok pesantren. Lebih dari itu, pondok pesantren sudah merupakan lembaga yang hampir tidak dapat digantikan fungsinya dengan badan lain. Kyai sebagi top figur pesantren telah melekat pada masyarakat di mana pesantren itu berada. Kyai tidak

\footnotetext{
${ }^{28}$ Lihat Nurcholish Madjid, Bilik-bilik Pesantren: Sebuah Potret Perjalanan (Jakarta: Paramadian, 1997), $5-6$.

${ }^{29}$ Pesantren modern dapat dipahami sebagai pesantren yang mengajarkan pelajaran-pelajaran umum di samping pelajaran-pelajaran agama dan pendidikan moral. Lihat Lukens-Bull, Jihad ala Pesantren, 86-7. ${ }^{30}$ Tentang orientasi perbedaan visi pembangunan dua orde, selanjutnya lihat Mochtar Mas'ud, Ekonomi dan Struktur Politik Orde Baru 1966-1971 (Jakarta; LP3ES, 1989).
} 
hanya dipandang sebagai konsultan agama akan tetapi menjadi konselor dan poros hubungan antara umat dengan Tuhan. ${ }^{31}$ Hal ini merupakan bukti bahwa masyarakat masih mempercayakan masalah-masalah hidupnya kepada pesantren. Tidak jarang ulama (kyai) dijadikan jastifikasi untuk memperlakukan sesuatu kemaslahatan di tengah-tengah masyarakat walaupun kadangkala kemaslahatan umat yang dikandungnya masih perlu dipertanyakan keabsahaannya. ${ }^{32}$

Transformasi pesantren ke arah modernitas untuk menyongsong pengaruh dari luar berupa pembangunan ekonomi yang digagas Orde Baru, sepenuhnya tergantung pada kyai sebagai figur pemimpin. Ada pesantren yang tetap mempertahankan misi pesantren sebagai lembaga tafaqquh fiddin, akan tetapi ada juga pesantren yang didesain sebagai lembaga yang bergerak di bidang sosial ekonomi keagamaan di samping pengkajian kitab-kitab klasik sebagai ciri khas pesantren. Pada pesantren tipe terakhir ini agenda ekonomi merupakan bagian dari misi pesantren. Istilah pesantren sebagai lembaga tafaqquh fiddin (ilmu-ilmu agama) telah mengalami pengembangan makna yaitu lembaga yang mendidik santri agar di samping menguasai ilmu-ilmu agama, juga memahami realitas masyarakat. Maka, para santri di samping mempelajari ilmu-ilmu agama juga diberi kesempatan untuk memperoleh keterampilan, baik melalui aktivitasaktivitas lembaga ekonomi yang ada di pesantren maupun melalui pelatihan-pelatihan keterampilan.

\section{Penutup}

Berdasarkan uraian di atas, beberapa poin penting dapat disimpulkan sebagai berikut: Melihat Indonesia sebagai negara dengan kemajemukan suku, etnik, agama dan budaya, diskursus dan implementasi Islam inklusif menemukan tempatnya yang berarti dan tentu saja pendidikan menjadi satu faktor penting. Sebagai sebuah cara pandang, Islam inklusif menjadi gagasan yang cukup kontekstual dengan realitas masyarakat kontemporer saat ini. Pendidikan dengan wawasan Islam inklusif merupakan konsep, ide atau falsafah sebagai suatu rangkaian kepercayaan dan penjelasan yang mengakui dan menilai pentingnya keragaman budaya dan etnis di dalam membentuk membentuk gaya hidup, pengalaman sosial, identitas pribadi, kesempatan-kesempatan pendidikan dari individu, kelompok maupun negara. Wawasan dan implementasi Islam inklusif

\footnotetext{
${ }^{31}$ Hiroko Horikoshi, Kyai Dan Perubahan Sosial (Jakarta; P3M, 1987), 232.

${ }^{32}$ Wahid Zaini, Dunia Pemikiran Kaum Santri (Yogyakarta; LPSM NU DIY, 1995), 140.
} 
dalam lembaga pendidikan Islam mendapat kritikan dari para pengamat karena telah mempraktikkan proses pendidikan yang eksklusif, dogmatik, dan kurang menyentuh aspek moralitas.

Peran pesantren sebagai sebuah lembaga yang muncul dan berkembang dari kultur budaya asli Indonesia, tampaknya tidak bisa dilepaskan peranannya dari akar budayanya. Fungsi pesantren yang pada awalnya hanyalah pengembangan intelektual Islam beralih fungsi menjadi pusat pengembangan masyarakat. Fenomena itu dapat mengikis anggapan sementara pengamat bahwa pesantren adalah gudang kekolotan. Berbagai fenomena yang dipaparkan patut diapresiasi sebagai sebuah potensi budaya yang perlu dilestarikan dan diperhitungkan sebagai potensi dan kekuatan budaya.

Keberhasilan mengkontekstualisasikan ini akan membuahkan dua gagasan penting. Pertama, proses transformasi sosial tidak dipandang sebagai hasil atau dampak dari lingkungan eksternal pesantren, akan tetapi lebih dari itu, pesantren mempunyai andil yang lebih besar dalam melakukan transformasi sosial kultural bagi masyarakat sekitarnya. Kedua, pengembangan pesantren tidak tercerabut dari akar tradisinya. Tradisi-tradisi pesantren tetap dipertahankan karena yang dibutuhkan dalam transformasi bukan penghancuran tradisi 


\section{Daftar Pustaka}

Abdul Munir Mulkhan, "Humanisasi Pendidikan Islam" dalam Tashwirul Afkar, Jurnal Refleksi Pemikiran Keagamaan dan Kebudayaan, Edisi No. 11 Tahun 2001.

dalam Politik" dalam Harian Kompas, Edisi Sabtu, 18 September 2004.

Abdurrahman Mas'ud, 2004, "Format Baru Pola Pendidikan Keagamaan pada Masyarakat Multikultural dalam Perspektif Sisdiknas" dalam Mu'amar Ramadhan dan Hesti Hardinah (ed.), Antologi Studi Agama dan Pendidikan Semarang: CV Aneka Ilmu.

Ahmad Fuad Fanani, 2002, "Pendidikan Pluralis-Multikultural dan Liberatif" dalam Harian Kompas, Edisi 3 Juli.

Amin Abdullah, "Pengajaran Kalam dan Teologi di Era Kemajemukan: Sebuah Tinjauan Materi dan Metode Pendidikan Agama" dalam Tashwirul Afkar, Jurnal Refleksi Pemikiran Keagamaan dan Kebudayaan, Edisi No. 11 Tahun 2001

, 2016, Studi Islam, Ilmu Humaniora, dan Sosial Sebuah Perspektif Terpadu, dalam Memahami Hubungan Antar Agama ( Surabaya, Sunan Ampel,

Azyumardi Azra, "Identitas dan Krisis Budaya: Membangun Multikulturalisme Indonesia," dalam Makalah, disampaikan pada Simposium Internasional Jurnal Antropologi Indonesia ke-3, Membangun Kembali Indonesia yang Bhinneka Tunggal Ika: Menuju Masyarakat Multikultural, 16-19 Juli 2002, di Universitas Udayana, Denpasar, Bali

Bhamra, T., dan Lofthouse, V., 2007, Design for Sustainability: A practical approach (A practical Approach), Gower Publishing Limited, Hampshire.

Charles Taylor. 1994, "The Politics of Recognation" dalam Amy Gutman. Multiculturalism, Examining the Politics of Recognation (Princenton: Princenton University Press.

Dawam Rahardjo, "Kyai dalam Perubahan Sosial," dalam Pesantren, No. 4/ Vol. II/1985

Erfan Maryono,"Aktualisasi Peran Kemasyarakatan Pesantren: Refleksi Pengalaman LPSM,” dalam Pesantren No. 3/Vol. V/1998.

Fathi Osman, 2006, The Childern of Adam; An Islamic Perspective on Pluralism, (terj.) Islam, Pluralisme dan Toleransi Keagamaan; Pandangan Alqur'an, Kemanusiaan, Sejarah, dan Peradaban, Jakarta,Paramadina. 
, 2001, Islam and Human Right, The Challenge to Muslim and The World, dalam Rethinking Islam and Modernity, ed. Abdel Wahab ElEffandi (London: The Islamic Foundation.

H.A.R. Tilaar, 2003, "Pendidikan Multikultural” dalam H.A.R. Tilaar, Kekuasaan dan Pendidikan: Suatu Tinjauan dari Perspektif Studi Kultural Magelang: Indonesia Tera,

Hawasi, 2005, "Aktualisasi Paradigma Multikulturalisme dalam Budaya Indonesia yang Plural” dalam Proceeding Seminar Nasional PESAT 2005 di Universitas Gunadarma, Yogyakarta.

Hiroko Horikoshi, 1987, Kyai Dan Perubahan Sosial ,Jakarta; P3M.

Jajat Burhanuddin,2003, "Ulama dan Politik Pembentukan Umat: Sekilas Pengalaman Sejarah Indonesia," dalam Jajat Burhanuddin dan Ahmad Baedlowi, Transformasi Otoritas Keagamaan: Pengalaman Islam Indonesia Jakarta; Gramedia.

James A. Banks. "Multicultural Education: Historical Development, Dimensions, and Practice" dalam James A. Banks dan Cherry A. McGee, op.

dan Cherry A. McGee (ed). 2001, Handbook of Research on Multicultural Education, San Francisco: Jossey-Bass.

Kymlica W.. Multicultural, 1995, Citizenship: a Liberal Theory of Minority Rights, Oxford: Clarendon Press.

Leo Suryadinata dkk., 2003, Indonesia's Population: Etnicity and Religion in a Changing Political Landscape (Singapore: Institute of Southeast Asian Studies.

Listia dkk., 2007, Problematika Pendidikan Agama di Sekolah: Hasil Penelitian tentang Pendidikan Agama di Yogyakarta 2004-2006, (Yogyakarta: Interfidei.

Martin Van Bruinessen, 2002, "Genealogies of Islamic Radicalism in post-Suharto Indonesia”, Southeast Asia Research no 2.

Mochtar Mas'ud, 1989, Ekonomi dan Struktur Politik Orde Baru 19661971 Jakarta; LP3ES,.

Muammar, M. Arfan, dkk. 2013, Studi Islam: Perspektif Insider/Outsider, Yogyakarta: IRCiSoD,

Muhammad Ali, 2002, "Pendidikan Pluralis-Multikulturalis" dalam Harian Kompas, Edisi 26 April.

Musa Asy'arie, 2004 "Pendidikan Multikultural dan Konflik Bangsa", dalam Harian Kompas, Edisi Jum’at, 3 September. 
Nurcholish Madjid, 1997Bilik-bilik Pesantren: Sebuah Potret Perjalanan Jakarta: Paramadian.

Pusat Kurikulum Balitbang Depdiknas RI, "Bab II: Prinsip Pengembangan Kurikulum" dalam 2006, Kurikulum Tingkat Satuan Pendidikan (KTSP) Jakarta: Puskur Balitbang Depdiknas,

Ronald Alan Lukens-Bull, 2004 Jihad ala Pesantren di Mata Antropolog Amerika (Yogyakarta: Gama Media.

Scott Lash dan Mike Featherstone (ed.), 2002, Recognition and Difference: Politics, Identity, Multiculture ,London: Sage Publication.

Steve Fuller, 2002, "Social Epistemology as a Critical Philosophy of Multiculturalism" dalam Ram Mahalingan dan Cameron McCarthy, Multiculturalism Curriculum,.

Wahid Zaini, 1995, Dunia Pemikiran Kaum Santri Yogyakarta; LPSM NU DIY. 